Jurnal Pemberdayaan: Publikasi Hasil Pengabdian kepada Masyarakat

Vol. 3, No. 2, Agustus 2019, Hal. 231-236

ISSN: 2580-2569; e-ISSN: 2656-0542

DOI: https://doi.org/10.12928/jp.v3i2.638

\title{
Pelatihan peningkatan kompetensi melakukan bimbingan kelompok bagi guru bimbingan dan konseling SMP di Kabupaten Sleman
}

\author{
Caraka Putra Bhakti, Sri Hartini, Mufied Fauziah \\ Universitas Ahmad Dahlan, Jl. Ring Road Selatan, Banguntapan, Bantul, Indonesia \\ Email: caraka.pb@bk.uad.ac.id
}

\begin{abstract}
ABSTRAK
Pelatihan ini bertujuan untuk meningkatkan kompetensi guru bimbingan dan konseling sekolah menengah pertama di kabupaten Sleman dalam aspek pengetahuan, keterampilan pelaksanaan layanan dan keterampilan penyusunan administrasi bimbingan kelompok baik Rencana Pemberian Layanan (RPL) maupun laporan. Pelatihan dilaksanakan menggunakan metode ceramah, workshop, dan role play. Kegiatan pelatihan dilaksanakan di SMPN 1 Ngaglik, dengan jumlah pertemuan empat kali, dengan satu kali pelatihan dilaksanakan selama 8 jam. Peserta pelatihan terdiri dari 31 Guru Bimbingan dan konseling yang berasal dari 31 sekolah di kabupaten Sleman. Teknik bimbingan kelompok yang dilatihkan meliputi teknik diskusi, sosiodrama, psikodrama dan permainan. Setelah kegiatan pelatihan berakhir, peserta memperoleh pemahaman, keterampilan pelaksanaan bimbingan kelompok dengan teknik diskusi, sosiodrama, psikodrama dan permainan serta mempu menyusun rencana dan laporan layanan bimbingan kelompok. Hasil pelatihan yang telah dilakukan meninjau dari dua aspek penilaian, yaitu kemampuan Guru BK dalam menyusun RPL dan kemampuan Guru BK dalam melakukan layanan bimbingan kelompok. Hasil analisis data pelatihan diperoleh bahwa dalam penyusunan RPL peserta kegiatan memperoleh skor rata-rata 35,85 dalam kategori baik. Hal tersebut menunjukkan bahwa peserta pelatihan telah memiliki keterampilan yang baik dalam menyusun RPL (Rencana Pemberian Layanan) bimbingan kelompok. Selanjutnya, hasil analisis data kemampuan peserta dalam melakukan layanan bimbingan kelompok menunjukkan skor 66,96 dalam kategori baik. Hal tersebut menunjukkan bahwa peserta memiliki kemampuan yang baik dalam melakukan layanan bimbingan kelompok.
\end{abstract}

Kata kunci: bimbingan, kelompok, pelatihan

\section{ABSTRACT}

The purpose of this training is carried out to improve the competence of teachers guidance and counseling junior high school in Sleman district in the aspect of knowledge, skills and service delivery skills better preparation of administrative guidance Planned Giving Services group (RPL) and report. Training will be conducted using the method of lectures, workshops and role play. The training activities conducted at SMPN 1 Ngaglik, with four times the number of meetings, where one training was held for 8 hours. Participants consisted of 31 teacher training Guidance and counseling came from 31 schools in Sleman district. Group counseling techniques are practiced include engineering discussions, sociodrama, psychodrama and games. Once the training is over, the participants gain an understanding, skill execution discussion group counseling techniques, sociodrama, psychodrama and games as well as plan and report mempu group counseling services. The result of the training has been done reviewing two aspects of assessment, namely the ability of teachers in developing RPL BK and BK Teacher capability in conducting group counseling services. Based on data analysis, it is known that in the preparation of RPL participants in obtaining an average score of 35.85 in both categories. It shows that the participants already have good skills in preparing RPL (Planned Giving Services) group counseling. The results of the data analysis capabilities of participants in conducting group counseling services showed a score of 66.96 in both categories. It shows that the participants have a good ability to conduct group counseling services.

Keywords: guidance, group, Training 


\section{PENDAHULUAN}

Layanan bimbingan dan konseling di sekolah dapat diberikan secara individu, kelompok maupun masyarakat. Jika menilik manusia sebagai makhluk sosial, maka manusia tidak dapat melepaskan diri dari manusia lainnya. Antara manusia yang satu dengan manusia yang lainnya saling membutuhkan dan saling berhubungan. Dalam hubungan ini akan terjadilah suatu proses saling mempengaruhi. Dalam kaitannya dengan kelompok, antara anggota satu dengan anggota kelompok yang lain akan terjadi saling mempengaruhi. Proses saling mempengaruhi ini dalam kehidupan kelompok itulah yang sebenarnya yang dijadikan landasan diselenggarakannya bimbingan kelompok (Wibowo, 2005).

Rusmana (2009) menjelaskan bahwa bimbingan kelompok merupakan proses pemberian bantuan yang diberikan pada individu dalam situasi kelompok. Bimbingan kelompok ditujukan untuk mencegah timbulnya masalah pada siswa dan mengembangkan potensi siswa. Secara umum dapat dikatakan bahwa sebagai salah satu teknik bimbingan, bimbingan kelompok mempunyai prinsip, kegiatan, dan tujuan yang sama dengan bimbingan. Perbedaannya hanya terletak pada pengolahannya, yaitu dalam situasi kelompok. Tujuan dari penyelenggaraan bimbingan kelompok di sekolah tidak jauh berbeda jika dibandingkan dengan tujuan program bimbingan pada umumnya, yaitu membantu setiap siswa supaya dapat berkembang seoptimal mungkin sesuai dengan potensi yang dimilikinya .

Bimbingan kelompok memungkinkan beberapa individu dapat memanfaatkan dinamika kelompok semaksimal mungkin dalam memecahkan masalahnya. Penggunaan teknik dalam kegiatan bimbingan kelompok mempunya banyak fungsi selain dapat lebih memfokuskan kegiatan bimbingan kelompok terhadap tujuan yang ingin dicapai tetapi juga dapat membuat suasana yang terbangun dalam kegiatan bimbingan kelompok agar lebih bergairah dan tidak cepat membuat siswa jenuh mengikutinya (Romlah, 2006).

Salah satu teknik dalam bimbingan kelompok adalah diskusi kelompok. Diskusi kelompok merupakan salah satu teknik bimbingan kelompok yang penting, malahan dapat dikatakan sebagai jantungnya bimbingan kelompok. Hampir semua teknik bimbingan kelompok menggunakan diskusi sebagai cara kerjanya, misalnya permainan peranan, karya wisata, permainan simulasi, pemecahan masalah, home room dan pemahaman diri melalui proses kelompok.

Salah satu kompetensi profesional konselor adalah melakukan layanan dalam situasi kelompok (Natawidjaya, 2009). Sejalan dengan pendapat tersebut sesuai dalam permendibud No. 111 Tahun 2014 tentang bimbingan dan konseling di sekolah dasar dan menengah, konselor memiliki peran penting dalam pelaksanaan layanan dasar. Salah satu layanan dasar adalah bimbingan kelompok.

\section{METODE}

Pelatihan ini diterapkan dengan beberapa metode pelatihan, diantaranya ceramah diberikan dengan materi; workshop, dilaksanakan dengan memberi contoh meningkatkan kemampuan pelaksanaan bimbingan kelompok, dan Role Play, pemberian contoh langsung kepada guru melalui simulasi dengan menerapkan materi persiapan layanan bimbingan kelompok, tahapan layanan, penggunaan teknik bimbingan kelompok, dan laporan pelaksanaan. Analisis data menggunakan analisis data kuantitatif dengan menggunakan instrument pengukuran berupa skala.

\section{HASIL, PEMBAHASAN, DAN DAMPAK}

Pelatihan bimbingan kelompok bagi guru Bimbingan dan Konseling di kabupaten Sleman telah terselenggara selama empat kali pertemuan. Empat pertemuan tersebut dilaksanakan dengan mengusung empat teknik dalam pelaksanaan bimbingan kelompok, yaitu 
teknik diskusi, sosiodrama, psikodrama dan permainan. Masing-masing pertemuan pelatihan dilaksanakan dalam tiga sesi, yaitu ceramah (memberikan penjelasan secara teoritis), workshop (memberikan contoh pelaksanaan) dan role play (memperagakan dengan cara melakukan simulasi). Adapun secara rinci deskripsi pelaksanaan pelatihan ialah sebagai berikut:

\section{Pertemuan 1 (Bimbingan Kelompok Teknik Diskusi)}

Pertemuan pertama dilaksanakan di SMPN 1 Ngaglik sleman pada hati Rabu, tanggal 12 September 2018 dengan agenda pembukaan dan pelaksanaan pelatihan pertemuan pertama. Kegiatan pelatihan dibuka langsung oleh kepala dinas pendidikan kabupaten sleman Dra. Sri Wantini, M.Pd., Ketua MGBK Sleman oleh Mulasih S.Pd. serta Dosen Bimbingan dan Konseling Universitas Ahmad Dahlan oleh Caraka Putra Bhakti. Pelaksanaan pelatihan pertemuan pertama dilakukan dalam tiga sesi.

Sesi pertama adalah ceramah dengan pemaparan materi tentang bimbingan kelompok secara umum, tahapan bimbingan kelompok, teknik diskusi dalam bimbingan kelompok, tiga cara dalam melaksanakan diskusi (diskusi panel, loka karya, dan diskusi terfokus) dan pemilihan materi dalam melakukan bimbingan kelompok. Sesi kedua dilaksanakan dengan tahan workshop. Peserta pelatiahan diberikan keterampilan mengenai penyusunan Rencana Pelaksanaan Layanan (RPL), penilaian RPL, praktik bimbingan kelompok dengan teknik diskusi, menyusun laporan, dan mengevaluasi laporan. Sesi ketiga adalah role play, dimana peserta diminta untuk melakukan simulasi pelaksanaan bimbingan kelompok dengan teknik diskusi. 31 peserta diminta untuk membentuk 3 kelompok kecil, dan masing-masing kelompok diminta untuk melakukan perencanaan dan simulasi layanan bimbingan kelompok dengan teknik diskusi dengan tiga variasi pilihan teknik yaitu diskusi panel, loka karya dan diskusi terfokus. Masing-masing kelompok kecil divasilitasi dengan satu orang observer yang telah disiapkan untuk mendampingi peserta pelatihan. Jika simulasi telah dilaksanakan, maka observer akan mereview praktik yang telah dilakukan dan mendiskusikan kesulitan-kesulitan yang dihadapi peserta. Sebagai penutupan kegiatan, evaluasi dilaksanakan secara klasikal untuk mengevaluasi pelaksanaan pelatihan yang telah dilakukan oleh masing-masing kelompok kecil.

\section{Pertemuan 2 (Bimbingan Kelompok Teknik Sosiodrama)}

Pertemuan kedua dilaksanakan di SMP Negeri 1 Ngaglik pada hari Rabu, 19 September 2018 dengan agenda pelaksanaan pelatihan bimbingan kelompok dengan teknik Sosiodrama. Pelatihan kedua dibuka oleh ketua MGBK Sleman oleh Mulasih S.Pd. mengenai pemantapan dan pengarahan peserta pelatihan kemudian dilanjutkan dengan pelaksanaan latihan. Pelatihan bimbingan kelompok teknik sosiodrama dilaksanakan dengan tiga sesi pelatihan, yaitu sesi ceramah, workshop dan role play. Sesi pertama adalah ceramah yang dilaksanakan dengan memberikan pemaparan tentang konsep bermain peran, komponen yang diperlukan dalam bermain peran, jenis bermain peran, pengertian sosiodrama, pemilihan tema dalam sosiodrama dan langkah-langkah pelaksanaan sosiodrama. Sesi kedua adalah workshop yang dilaksanakan dengan melakukan pelatihan dalam menyusun Rencana Pelaksanaan Layanan (RPL), penilaian RPL, praktik bimbingan kelompok dengan teknik sosiodrama dengan bantuan video, menyusun laporan, dan mengevaluasi laporan. Sesi ketiga adalah role play, dimana peserta diminta untuk melakukan simulasi pelaksanaan bimbingan kelompok dengan teknik sosiodrama. Peserta diminta untuk membentuk 3 kelompok kecil, dan masing-masing kelompok diminta untuk menentukan tema yang akan dipraktikkan dalam simulasi sosiodrama. Ketika masing-masing kelompok telah menentukan tema, lalu kelompok diminta menyusun alur cerita yang akan diperagakan dalam sosiodrama. Masing-masing kelompok 
kecil difasilitasi dengan satu orang observer yang telah disiapkan untuk mendampingi peserta pelatihan. Jika simulasi telah dilaksanakan, maka observer akan mereview praktik yang telah dilakukan dan mendiskusikan kesulitan-kesulitan yang dihadapi peserta. Sebagai penutupan kegiatan, evaluasi dilaksanakan secara klasikal untuk mengevaluasi pelaksanaan pelatihan yang telah dilakukan oleh masing-masing kelompok kecil.

\section{Pertemuan 3 (Bimbingan Kelompok Teknik Psikodrama)}

Pertemuan ketiga dilaksanakan di SMP Negeri 1 Depok pada hari Rabu, 3 Oktober 2018 dengan agenda pelaksanaan pelatihan bimbingan kelompok dengan teknik Psikodrama. Pelatihan ketiga dibuka oleh ketua MGBK Sleman oleh Mulasih S.Pd. dan dilanjutkan dengan pelaksanaan latihan. Pelatihan bimbingan kelompok teknik psikodrama dilaksanakan dengan tiga sesi pelatihan, yaitu sesi ceramah, workshop dan role play. Sesi pertama adalah ceramah yang dilaksanakan dengan memberikan pemaparan tentang konsep sosiodrama, perbedaan antara sosiodrama dan psikodrama, langkah-langkah pelaksanaan psikodrama, dan teknik tambahan dalam psikodrama (bertukar peran, peran ganda, teknik cermin, kursi kosong, dan monodrama). Sesi kedua adalah workshop yang dilaksanakan dengan melakukan pelatihan dalam menyusun Rencana Pelaksanaan Layanan (RPL), penilaian RPL, praktik bimbingan kelompok dengan teknik psikodrama menggunakan bantuan video, menyusun laporan, dan mengevaluasi laporan. Sesi ketiga adalah role play, dimana peserta diminta untuk melakukan simulasi pelaksanaan bimbingan kelompok dengan teknik psikodrama. Peserta diminta untuk membentuk 3 kelompok kecil, dan masing-masing kelompok diminta untuk menentukan tema yang akan dipraktikkan dalam simulasi psikodrama. Ketika masing-masing kelompok telah menentukan tema, lalu kelompok diminta menyusun alur cerita yang akan diperagakan dalam psikodrama. Masing-masing kelompok kecil difasilitasi dengan satu orang observer yang telah disiapkan untuk mendampingi peserta pelatihan. Jika simulasi telah dilaksanakan, maka observer akan mereview praktik yang telah dilakukan dan mendiskusikan kesulitan-kesulitan yang dihadapi peserta. Sebagai penutupan kegiatan, evaluasi dilaksanakan secara klasikal untuk mengevaluasi pelaksanaan pelatihan yang telah dilakukan oleh masing-masing kelompok kecil.

\section{Pertemuan 4 (Bimbingan Kelompok Teknik Permainan)}

Pertemuan keempat dilaksanakan di SMP Negeri 1 Ngaglik pada hari Rabu, 11 Oktober 2018 dengan agenda pelaksanaan pelatihan bimbingan kelompok dengan teknik permainan dan penutupan kegiatan pelatihan. Pelatihan keempat ini dibuka oleh ketua MGBK Sleman oleh Mulasih S.Pd. dengan pengarahan yang ditujukan pada peserta kegiatan dan dilanjutkan dengan pelaksanaan latihan. Pelatihan bimbingan kelompok teknik permainan dilaksanakan dengan tiga sesi pelatihan, yaitu sesi ceramah, workshop dan role play. Sesi pertama adalah ceramah yang dilaksanakan dengan memberikan pemaparan tentang konsep teknik permainan dalam bimbingan kelompok, keunggulan teknik permainan dalam bimbingan kelompo, jenisjenis permainan yang dapat digunakan dalam bimbingan kelompok, cara membuat permainan simulasi, dan hal-hal yang perlu diperhatikan dalam menyusun permainan. Sesi kedua adalah workshop yang dilaksanakan dengan melakukan pelatihan dalam menyusun Rencana Pelaksanaan Layanan (RPL), penilaian RPL, praktik bimbingan kelompok dengan teknik permainan menggunakan bantuan video, menyusun laporan, dan mengevaluasi laporan. Sesi ketiga adalah role play, dimana peserta diminta untuk melakukan simulasi pelaksanaan bimbingan kelompok dengan teknik permainan. 31 peserta diminta untuk membentuk 3 kelompok kecil, dan masing-masing kelompok diminta untuk menentukan tema yang akan dipraktikkan dalam simulasi permainan. Setelah menentukan tema yang akan diangkat, peserta diminta untuk menentukan permainan apa yang dapat digunakan untuk menyampaikan materi 
dalam bimbingan kelompok. Setelah diperoleh kesepakatan tentang tema dan jenis permainan, kemudian peserta diminta untuk berbagi peran, dan salah satu peserta diminta memperagakan sebagai konselor sekolah, kemudian dilakukan simulasi. Masing-masing kelompok kecil difasilitasi dengan satu orang observer yang telah disiapkan untuk mendampingi peserta pelatihan. Jika simulasi telah dilaksanakan, maka observer akan mereview praktik yang telah dilakukan dan mendiskusikan kesulitan-kesulitan yang dihadapi peserta. Kegiatan role play diakhiri dengan evaluasi yang dilaksanakan secara klasikal untuk mengevaluasi pelaksanaan pelatihan yang telah dilakukan oleh masing-masing kelompok kecil. Acara dilanjutkan dengan agenda penutupan rangkaian kegiatan pelatihan bimbingan kelompok pada guru SMP di Kabupaten Sleman. Kegiatan ditutup oleh ketua MGBK Kabupaten Sleman yaitu Mulasih, S.Pd.

Sebagai evaluasi ketercapaian tujuan pelatihan, peserta diberikan tugas untuk menyusun Rencana Pemberian Layanan (RPL) Bimbingan Kelompok beserta Video pelaksanaan layanan dengan siswa di sekolah masing-masing.

Hasil pelatihan selama empat kali pertemuan menunjukkan sebagai berikut:

1. Kemampuan Menyusun RPL (Rencana Pemberian Layanan)

Kemampuan Guru Bimbingan dan Konseling dalam menyusun RPL diukur menggunakan lembar penilaian rencana pelaksanaan layanan bimbingan kelompok . Lembar penilaian ini menilai mengenai ketepatan perencanaan layanan baik dalam pemilihan topik, tujuan, metode serta kejelasan layanan yang akan diberikan menggunakan penilaian skala 4. Berdasarkan hasil analisis data, diketahui bahwa peserta kegiatan memperoleh skor rata-rata 35,85 dalam kategori baik. Hal tersebut menunjukkan bahwa peserta pelatihan telah memiliki keterampilan yang baik dalam menyusun RPL (Rencana Pemberian Layanan) bimbingan kelompok.

2. Kemampuan Melakukan Layanan Bimbingan Kelompok

Kemampuan Guru Bimbingan dan Konseling dalam melakukan layanan bimbingan kelompok diukur menggunakan lembar pengamatan praktik strategi layanan bimbingan kelompok. Lembar pengamatan ini berisi aspek-aspek yang hendaknya dikuasai oleh Guru Bimbingan dan Konseling dalam melakukan layanan bimbingan kelompok dengan menggunakan penilaian skor skala 4 yang dapat dilihat dalam lampiran. Berdasarkan hasil analisis yang telah dilakukan, diperoleh data bahwa nilai rata-rata Guru Bimbingan dan Konseling dalam memberikan layanan bimbingan kelompok adalah 66,96, dengan mengacu pada kategorisasi seperti tampak pada Tabel 1, sehingga dapat diketahui bahwa kemampuan peserta pelatihan berada pada kategori baik. Hal tersebut menunjukkan bahwa peserta memiliki kemampuan yang baik dalam melakukan layanan bimbingan kelompok

Tabel 1. Kategorisasi Skor Evaluasi Kemampuan Melakukan Bimbingan Kelompok

\begin{tabular}{cc}
\hline Kategorisasi & Skor \\
\hline Baik & $60-80$ \\
Sedang & $41-59$ \\
Buruk & $20-40$ \\
\hline
\end{tabular}

Tabel 2 menunjukkan bahwa penilaian pada masing-masing tahapan bimbingan kelompok, berbeda-beda pada setiap tahapan, mulai dari sedang sampai baik. 
Tabel 2. Kemampuan Melakukan Bimbingan Kelompok Pada Masing-Masing Tahapan

\begin{tabular}{lll}
\hline \multicolumn{1}{c}{ Tahapan Bimbingan Kelompok } & \multicolumn{1}{c}{ Skor } & \multicolumn{1}{c}{ Keterangan } \\
\hline Tahap Awal & 19,16 & Baik \\
Tahap Peralihan / Transisi & 10,96 & Sedang \\
Tahap Kegiatan Inti & 17,07 & Baik \\
Tahap Penutup & 19,77 & Baik \\
\hline
\end{tabular}

Jacobs, dkk. (2016) menjelaskan bahwa layanan kelompok merupakan salah satu layanan strategis dalam mendampingi pengemnbangan potensi siswa. Hal ini sejalan dengan pendapat Corey (2012) yang menganjurkan layanan dalam format kelompok dikuasai secara mendalam oleh guru bimbingan dan konseling dan Kemendikbud (2016) yang merekomendasikan bimbingan kelompok salah satu strategi dalam komponen layanan dasar.

\section{SIMPULAN}

Hasil pelatihan yang telah dilakukan meninjau dari dua aspek penilaian, yaitu kemampuan Guru BK dalam menyusun RPL dan kemampuan Guru BK dalam melakukan layanan bimbingan kelompok. Berdasarkan analisis data, diketahui bahwa dalam penyusunan RPL peserta kegiatan memperoleh skor rata-rata 35,85 dalam kategori Baik. Hal tersebut menunjukkan bahwa peserta pelatihan telah memiliki keterampilan yang baik dalam menyusun RPL (Rencana Pemberian Layanan) bimbingan kelompok. Hasil analisis data kemampuan peserta dalam melakukan layanan bimbingan kelompok menunjukkan skor 66,96 dalam kategori baik. Hal tersebut menunjukkan bahwa peserta memiliki kemampuan yang baik dalam melakukan layanan bimbingan kelompok.

\section{UCAPAN TERIMAKASIH}

Terima kasih kepada Lembaga Penelitian dan Pengabdian Masyarakat Universitas Ahmad Dahlan yang telah memberikan support dana bagi kegiatan ini. Dinas Pendidikan Kabupaten Sleman yang telah memberikan ijin dan dukungan terlaksananya pelatihan ini. Terima kasih kepada Musyawarah Guru Bimbingan dan Konseling Tingkat SMP Kabupaten Sleman atas semangat dan kerjasamnya selama kegiatan pelatihan ini.

\section{DAFTAR PUSTAKA}

Corey, G. (2012). Theory and Practice of Group Counseling. New York: Brooks/Cole.

Jacobs, E.E., Masson, R.L., Harvill, R.L., \& Schimmel, C.J. (2016). Group Counseling:

Strategies and Skills. New York: Cengage learning.

Kemendikbud. (2016). Panduan Operasional Penyelenggaraan Bimbingan dan Konseling. Jakarta: Kemendikbud.

Natawidjaja, R. (2009). Konseling Kelompok: Konsep Dasar dan Pendekatan. Bandung: Rizqi.

Permendikbud No. 111 Tahun 2014 tentang Bimbingan dan Konseling di Sekolah Dasar dan Menengah.

Romlah, T. (2006). Teori dan Praktek Bimbingan Kelompok. Malang: UMM Press.

Rusmana, N. (2009). Bimbingan dan Konseling Kelompok di Sekolah (Metode, Teknik dan Aplikasi). Bandung: Rizqi.

Wibowo, M.E. (2005). Konseling Kelompok Perkembangan. Semarang: UNNES Press. 